\title{
Research on the Influence of Teacher Variables on Students' Mathematical Achievements
}

\author{
Shengnan Bai, Jiwei Han, Canhui Li \\ Northeast Normal University, Changchun, China
}

\begin{abstract}
Based on the TIMSS2015 data, this study applied a hierarchical linear model to explore the influence of teacher variables on students' mathematics scores. Teacher variables were composed of teacher characteristic variables, teacher teaching variables, and teacher professional development variables. The teacher's characteristic variables were teaching age, gender, education, mathematics major, and mathematics education. Teachers' teaching variables were teaching expectations, teaching cooperation, teaching enthusiasm, classroom discussion, multimedia use, attention to homework, and emphasis on exams. Teacher professional development variables had mathematics knowledge training, mathematics education training, and mathematics curriculum training. Multi-layer linear analysis found that in the teacher's characteristic variables, the teacher's teaching age, gender, education, and mathematics major have a significant effect on the students' mathematics scores; In the teacher's teaching variables, teachers' teaching expectations, teaching enthusiasm, class discussion, and multimedia use have a significant impact on students' mathematics scores. In the teacher professional development variables, participation in mathematics knowledge training and mathematics education training had a significant positive impact on students' mathematics scores.
\end{abstract}

Best Evid Chin Edu 2019; 3(2):347-360.

Doi: 10.15354/bece.19.ar1266.

Keywords: Teacher Characteristic Variables; Teacher Teaching Variables; Teacher Professional Development Variables; Mathematics Scores

Correspondence to: Jiwei Han, Ph.D., Professor, School of Mathematics and Statistics, Northeast Normal University, Changchun, China. Email: hanjw617@nenu.edu.cn.

About the Author: Shengnan Bai, Ph.D., School of Mathematics and Statistics, Northeast Normal University, Changchun, China. Email: baisn012@nenu.edu.cn. 


\section{Problem}

$\mathrm{I}$

$\mathrm{N}$ the evaluation of education quality, the learning effect of students has always been regarded as an important dimension to examine the effect of education. Among them, student achievement is one of the main indicators reflecting the effect of learning. Teachers are often considered to be the main factor affecting students' academic performance. Therefore, exploring the influence of teacher variables on students' academic performance through research has always been an essential research issue in educational research. The research of this problem can provide theoretical basis for improving students' learning, promoting the fair distribution of educational resources and the effective training of teacher education. It is a critical problem that has been continuously explored in the field of education.

Throughout the study of the influence of teacher variables on students' academic performance, it can be roughly divided into three categories. The first category was to study the influence of teacher characteristic variables on students' academic performance. The conclusions from this problem study are not the same. Huang and Xin found that teachers' gender, teaching age, education, and majors had no significant influence on students' academic performance (Huang \& Xin, 2007); whereas Zhang found that teachers' gender, teaching age, and majors had a significant impact on student achievement (Zhang, 2012). The second category was to study the influence of teachers' teaching variables on students' academic performance. Teachers' teaching variables such as teacher's teaching plan, teaching behavior ( Peterson, et al., 1978) (class introduction, classroom language, classroom questions, classroom feedback, class waiting, class summary (Huang, et al., 2009; Zhou \& Bao, 2012; Huang, 2016; Gao \& Zhang, 2016; Cao \& Yu, 2017), teaching strategy (Walsh-Cavazos, 1994), teaching attitude (Bülent \& Erden, 2006) were important factors affecting students' academic performance, and some teachers' teaching variables such as teacher's teaching cooperation and classroom discussion had no significant influence on students' academic performance (Zhang, 2010). The third category was to study the influence of teacher professional development variables on students' academic performance. Zhang and Xin found that teachers' preparation methods, peer listening courses, and teaching and research participation had no significant effect on student achievement (Zhang, 2010); but Zhao and Yan found that teachers' preparation ways, training participation, peer-to-peer assessment, and teaching and research participation have a significant impact on student achievement (Zhao, et al., 2013). From these studies we can find that although the teacher variables were closely related to the students' academic performance, the conclusions had not yet reached a consistent agreement. There are two reasons for this: first, the measurement tools developed by the researchers were different, and the quality of the different measurement tools was directly related to the research results. Herlihy et al

About the Author: Canhui Li, School of Mathematics and Statistics, Northeast Normal University, Changchu, China.Email: lich380@nenu.edu.cn.

Conflict of Interests: None. 
indicated that the validity and reliability of the teacher evaluation system affect the conclusion of the role of teacher variables on student achievement (Herlihy, et al., 2005); second, the statistical analysis methods of choice are different, previous studies have not considered the Hierarchicaled nesting structure of teacher and student data, and traditional regression analysis of teacher variables and student variables as independent variables may cause bias in the results.

The research on the influence of teacher variables on students' academic performance has made two new developments in recent years. On the one hand, the quality of the measuring tools has improved. With the international emphasis on basic education, the emergence of international evaluation projects such as TIMSS and PISA has largely contributed to the improvement of the quality of measurement tools, which has led researchers to pay attention to the development of measurement tools, thereby promoting the quality of measurement tools. On the other hand, the methods of education statistics have been improved and improved. Samples of social science research often come from different levels and units. The resulting data is usually multi-level nested data, and the general statistical methods have problems for the processing of nested data. Therefore, with the continuous development of social sciences, Hierarchical linear models have begun to enter the eyes of educational researchers. This model solves the limitations of traditional regression analysis in dealing with multi-level nested data and becomes a new method of educational statistics research. In this context, we try to directly use the eighth-grade measurement data in TIMSS2015, and use the Hierarchical Linear Model (HLM) to analyze the influence of teacher variables on students' mathematics scores. In order to find teacher variables that can promote student achievement, this study proposes the following three questions:

- Question 1: How does the teacher characteristic variable affect student mathematics scores?

- Question 2: How does the teacher's teaching variable affect student mathematics scores?

- Question 3: What effect does the teacher's professional development variable have on student mathematics?

\section{Methodology}

\section{Data Selection}

The TIMSS project focuses on the development of students' mathematical and scientific academic achievements. TIMSS2015 collects information from students, teachers, and schools and encodes data by standardizing tests, questionnaires, and observing video lessons.

In TIMSS2015, a total of 45 countries participated in the eighth-grade standardized test. This study selected data from all countries participating in the eighth grade test and referred to it as TIMSS2015 data. All data is from the official TIMSS website (http://timssandpirls.bc.edu/timss2015/). 
The subjects of this study were selected from the data of TIMSS2015. After eliminating the missing values of the relevant variables and satisfying at least 20 students per teacher, there are 45,321 student samples, the ratio of male to female is 1:1.4; the number of teachers is 1,806 , and the ratio of male to female is $1: 1.2$.

\section{Variable Selection and Description}

Based on the data of TIMSS2015, this study explored the influence of teacher variables on students' mathematics scores based on the control of student variables in the nested relationship between students and teachers. Based on previous researches, the recent exploration of student family factors, teacher teaching factors and teacher professional development factors were introduced. At the same time, the TIMSS2015 standardized test questions and questionnaires were also adjusted and introduced into the study. Therefore, the dependent variable of this study is the student's mathematics score. The independent variable is divided into two layers:

- The first level is the student variables, which are divided into student background variables and learning motivation variables. Among them, student background variables: gender, age, family book collection, home computer, home learning desk, mobile phone, parental education (mother education, father education); learning motivation variables: mathematics learning interest, mathematics self-confidence. According to the Pearson correlation analysis, the mother's education and father's education are highly correlated, so the principal component analysis is used to form a new variable of parental education; other variables are not highly correlated. Table 1 shows the definition and scoring of student variables.

- The second level is the teacher variable, which is divided into teacher characteristic variables, teacher teaching variables and teacher professional development. Among them, teacher characteristic variables: teaching age, gender, education, mathematics major, mathematics education major; teacher teaching variables: teaching expectation, teaching cooperation, teaching enthusiasm, classroom discussion, multimedia use, attention to homework, emphasis on exams; teacher profession development variables: mathematics knowledge training, mathematics education training, mathematics curriculum training. After Pearson correlation analysis, the teacher variables did not reach a high level of correlation. Table 2 shows the definition and scoring method of teacher variables.

\section{Data Analysis}

Based on the data of TIMSS2015, this paper uses SPSS22.0 to organize data and use HLM6.08 for Hierarchical linear analysis. Taking the student's mathematics score as the dependent variable, without adding the independent variable, a zero model is established to test whether the sample data is suitable for Hierarchical linear analysis. On this basis, students and teacher variables are added to the previous model one by one to es- 
Table 1. Definition and Scoring of Student Variables.

\begin{tabular}{|c|c|c|}
\hline Variable & Variable Description & Scoring Method \\
\hline \multicolumn{3}{|l|}{ Student Variable } \\
\hline Age & $\begin{array}{l}\text { Calculated from the year } \\
\text { of birth and month }\end{array}$ & Continuous type \\
\hline Gender & Student gender & $\begin{array}{l}\text { Discrete } 2 \text { - point scoring, } 1 \text { for women, } 2 \\
\text { for men }\end{array}$ \\
\hline Family Collection & Family book collection & $\begin{array}{l}\text { Discrete } 5 \text { - point scoring, the higher the } \\
\text { score, the more books }\end{array}$ \\
\hline Home Computer & $\begin{array}{l}\text { Is there a computer in the } \\
\text { house? }\end{array}$ & Discrete 2 - point scoring, 1 is yes, 2 is no \\
\hline Home Desk & $\begin{array}{l}\text { Does the student have a } \\
\text { desk? }\end{array}$ & Discrete 2 - point scoring, 1 is yes, 2 is no \\
\hline Mobile Phone & $\begin{array}{l}\text { Does the student have a } \\
\text { mobile phone? }\end{array}$ & Discrete 2 - point scoring, 1 is yes, 2 is no \\
\hline Parental Education & & $\begin{array}{l}\text { (new variables formed by mother's edu- } \\
\text { cation and father's education) }\end{array}$ \\
\hline Math Interest & $\begin{array}{l}\text { Do students like to learn } \\
\text { mathematics? }\end{array}$ & $\begin{array}{l}\text { Discrete 4- point scoring, the higher the } \\
\text { score, the lower the mathematical inter- } \\
\text { est }\end{array}$ \\
\hline $\begin{array}{l}\text { Mathematics Self- } \\
\text { Confidence }\end{array}$ & $\begin{array}{l}\text { Learning mathematics } \\
\text { confidence }\end{array}$ & $\begin{array}{l}\text { Discrete 4- point scoring, the higher the } \\
\text { score, the lower the confidence }\end{array}$ \\
\hline
\end{tabular}

tablish five models. For example, model 2 is based on model 1 to add student learning motivation variables, and finally form a complete Hierarchical linear model. On the basis of controlling student variables, the influence of teacher variables on students' mathematics scores is investigated.

The specific model is expressed as follows:

First level: student level

Dependent variable:

$$
Y_{i j}=\beta_{0 j}+r_{i j}
$$

Second level: teacher level

$$
\beta_{0 j}=\gamma_{00}+\gamma_{01} \text { (teach year) }+\gamma_{02} \text { (gender) }+\cdots+\mu_{0 j}
$$

subscripts "j" and "i" in the expression of the Hierarchical linear model represent the teacher's number and the student's individual number, respectively, and "ij" is the $\mathrm{i}^{\text {th }}$ student in the $\mathrm{j}^{\text {th }}$ class. $\beta_{0 \mathrm{j}}$ represents the mathematical average of the students taught by the $\mathrm{j}^{\text {th }}$ teacher. If the difference between teachers reaches a significant level, it is necessary to further analyze which factors of the teacher make the students' mathematics scores show significant differences.

The establishment of a Hierarchical linear model is presented in Table 3. 


\section{Table 2. Teacher Variables of the Definition and Scoring.}

\begin{tabular}{|c|c|c|}
\hline Variable & Variable Description & Scoring Method \\
\hline \multicolumn{3}{|l|}{ Teacher Variable } \\
\hline \multicolumn{3}{|c|}{ Teacher Characteristic Variable } \\
\hline Teaching Age & Years of teaching & Continuous type \\
\hline Gender & & Consistent with student gender \\
\hline Education & & $\begin{array}{l}\text { Discrete } 7 \text { - point scoring, the higher } \\
\text { the score, the higher the education }\end{array}$ \\
\hline Mathematic Major & $\begin{array}{l}\text { Whether the field of study is } \\
\text { mathematics }\end{array}$ & $\begin{array}{l}\text { Discrete } 2 \text { - point scoring, } 1 \text { is yes, } 2 \\
\text { is not }\end{array}$ \\
\hline $\begin{array}{l}\text { Mathematics Educa- } \\
\text { tion }\end{array}$ & $\begin{array}{l}\text { Is the field of study a math- } \\
\text { ematics education? }\end{array}$ & $\begin{array}{l}\text { Discrete 2-point scoring, } 1 \text { is yes, } 2 \\
\text { is not }\end{array}$ \\
\hline \multicolumn{3}{|c|}{ Teacher Teaching Variable } \\
\hline $\begin{array}{l}\text { Teaching Expecta- } \\
\text { tion }\end{array}$ & $\begin{array}{l}\text { Teachers' expectations for } \\
\text { classroom teaching }\end{array}$ & $\begin{array}{l}\text { Discrete 5- point scoring, the higher } \\
\text { the score, the lower the expectation }\end{array}$ \\
\hline $\begin{array}{l}\text { Teaching Coopera- } \\
\text { tion }\end{array}$ & $\begin{array}{l}\text { Degree of cooperation be- } \\
\text { tween teachers }\end{array}$ & $\begin{array}{l}\text { Discrete 4- point scoring, the higher } \\
\text { the score, the lower the cooperation } \\
\text { frequency }\end{array}$ \\
\hline Teaching Passion & Degree of love for teaching & $\begin{array}{l}\text { Discrete } 4-\text { point scoring, the higher } \\
\text { the score, the lower the level of en- } \\
\text { thusiasm }\end{array}$ \\
\hline Class Discussion & $\begin{array}{l}\text { Frequency of discussion } \\
\text { among students in the class- } \\
\text { room }\end{array}$ & $\begin{array}{l}\text { Discrete } 4 \text { - point scoring, the higher } \\
\text { the score, the lower the discussion } \\
\text { frequency }\end{array}$ \\
\hline Multimedia Use & $\begin{array}{l}\text { Whether to use multimedia } \\
\text { in classroom teaching }\end{array}$ & $\begin{array}{l}\text { Discrete 2-point scoring, } 1 \text { is yes, } 2 \\
\text { is not }\end{array}$ \\
\hline $\begin{array}{l}\text { Pay Attention To } \\
\text { Homework }\end{array}$ & $\begin{array}{l}\text { Frequency of arranging math } \\
\text { assignments }\end{array}$ & $\begin{array}{l}\text { Discrete 5- point scoring, the higher } \\
\text { the score, the more important }\end{array}$ \\
\hline $\begin{array}{l}\text { Pay Attention To } \\
\text { The Exam }\end{array}$ & $\begin{array}{l}\text { Emphasis on classroom } \\
\text { tests }\end{array}$ & $\begin{array}{l}\text { Discrete 3- point scoring, the higher } \\
\text { the score, and the less important it is. }\end{array}$ \\
\hline \multicolumn{3}{|c|}{ Teacher Professional Development Variable } \\
\hline $\begin{array}{l}\text { Mathematical } \\
\text { Knowledge Training }\end{array}$ & $\begin{array}{l}\text { Whether to participate in } \\
\text { mathematics knowledge } \\
\text { training }\end{array}$ & $\begin{array}{l}\text { Discrete } 2 \text { - point scoring, } 1 \text { for partic- } \\
\text { ipation, } 2 \text { for not participating }\end{array}$ \\
\hline $\begin{array}{l}\text { Mathematics Educa- } \\
\text { tion Training }\end{array}$ & $\begin{array}{l}\text { Whether to participate in } \\
\text { mathematics education train- } \\
\text { ing }\end{array}$ & $\begin{array}{l}\text { Discrete } 2 \text { - point scoring, } 1 \text { for partic- } \\
\text { ipation, } 2 \text { for not participating }\end{array}$ \\
\hline $\begin{array}{l}\text { Mathematics Course } \\
\text { Training }\end{array}$ & $\begin{array}{l}\text { Whether to participate in } \\
\text { mathematics training }\end{array}$ & $\begin{array}{l}\text { Discrete } 2 \text { - point scoring, } 1 \text { for partic- } \\
\text { ipation, } 2 \text { for not participating }\end{array}$ \\
\hline
\end{tabular}

\section{Results}

According to the statistical principle of the Hierarchical linear model, in order to explore the influence of teacher variables on students' mathematics scores, the first is to establish a zero model to estimate the contribution of teacher-to-teacher differences and intra-teacher differences (student differences) to the total difference, if the difference 


\section{Table 3. Establishment of Hierarchical Linear Model.}

\begin{tabular}{lll}
\hline \multicolumn{2}{l}{$\begin{array}{l}\text { Zero } \\
\text { Model }\end{array}$} & Teacher Variable \\
\hline Model & $\begin{array}{l}\text { Student background variable: } \\
\text { Gender, age, family book collec- } \\
\text { tion, home computer, home desk, } \\
\text { mobile phone, parental education }\end{array}$ \\
\hline Model & $\begin{array}{l}\text { Students learn motivation varia- } \\
\text { bles: }\end{array}$ & \\
2 & $\begin{array}{l}\text { Mathematical learning interest, } \\
\text { mathematics self-confidence }\end{array}$ & \\
\hline Model & & $\begin{array}{l}\text { Teacher feature variables: } \\
\text { Teaching age, gender, education, mathemat- } \\
\text { ics major, mathematics education }\end{array}$ \\
\hline Model & & $\begin{array}{l}\text { Teacher teaching variables: } \\
\text { Teaching expectations, teaching cooperation, } \\
\text { teaching enthusiasm, class discussion, multi- } \\
\text { media use, attention to homework, and em- } \\
\text { phasis on exams }\end{array}$ \\
\hline Model & & $\begin{array}{l}\text { Teacher professional development variables: } \\
\text { Mathematical knowledge training, mathemat- } \\
\text { ics education training, mathematics course } \\
\text { training }\end{array}$ \\
\hline
\end{tabular}

between teachers is significant, it is necessary to further analyze which teacher variables make the students' mathematics scores show significant differences. The zero model results are presented in Table 4.

It can be seen from Table 4 that the intra-class correlation coefficient ICC of the student's math score is 0.68 , which means that about $68.42 \%$ of the total difference in the student's math score is caused by the teacher variable. At the same time, when the ICC is greater than 0.138, the difference between groups is significant (Dedrick, et al., 2009). This indicates that there is a significant difference between teachers, that is, the difference in mathematics scores of different teachers has reached a significant level ( $p<0.001$ ), which is consistent with previous empirical findings ( $\mathrm{Li} \& \mathrm{Ni}, 2006$ ).

Because of the significant differences among teachers, this study adds the three aspects of teacher variables to the second level of independent variables, and examines their influence on students' mathematics scores, thus providing some theoretical references for the improvement of teachers' teaching process. Due to space limitations, the full results of each model are listed in Table 5.

\section{The Influence of Teacher Characteristic Variables on Students' Mathematical Achievements}


Table 4. Estimation of Differences between Teachers and within

Teachers in Mathematics Scores.

\begin{tabular}{llll}
\hline & Variance & Standard Error & Contribution Rate \\
\hline Inter-Teacher & $8,900.70$ & 94.34 & $68.42 \%$ \\
\hline Intra-Teacher & $4,107.92$ & 64.09 & $31.58 \%$ \\
\hline
\end{tabular}

Model 3 is to examine the impact of teacher characteristic variables on students' mathematical performance. The survey results showed: teacher's teaching age $(b=1.09, \mathrm{p}<$ $0.001)$, gender $(b=-8.98, p=0.025)$, education $(b=48.84, p<0.001)$, mathematics major $(b=12.20, p=0.005)$. The impact on students' mathematics scores has reached a significant level. Compared with teachers with shorter teaching ages, teachers with longer teaching ages will have better mathematics scores for teachers who teach older classes. Female teachers have better math scores than those taught by male teachers. The higher the teacher's academic qualifications, the better the mathematics scores of the students in the taught class will be. Students in classes taught by non-mathematics teachers have higher math scores than those who were taught by teachers who graduated from mathematic major. In addition, the teacher characteristic variable explained $15.12 \%$ of the student's average math score difference.

\section{The Influence of Teachers' Teaching Variables on Students' Mathematical Achievements}

Model 4 includes the teacher's teaching variables based on Model 3, aiming to examine the influence of teacher's teaching variables on students' mathematics scores. The results of Model 4 indicate: teacher's teaching expectations $(b=-23.53, p<0.001)$, teaching enthusiasm $(b=9.72, p=0.002)$, class discussion $(b=18.01, p<0.001)$, multimedia use $(b=-11.90, p=0.005)$ has a significant impact on students' math scores. The higher the teacher's teaching expectation and the higher the frequency of multimedia use, the more helpful the mathematics scores of the students in this class. The higher the number of class discussions, the less effective the teaching. The teacher's enthusiasm for teaching has a negative predictive ability for students' mathematics scores. This may be due to the occurrence of the "Simpson's Paradox" or the poor original grades of the corresponding students of the teachers. The specific reasons still need further investigation and research. In addition, the teacher's teaching variables reduce the variance of students' mathematics scores to 6556.75 , explaining $8.85 \%$ of the students' average math scores.

\section{The Influence of Teachers' Professional Development Varia- bles on Students' Mathematical Achievements}


Model 5 is based on Model 4 and incorporates three variables of teacher professional development. The main examination is the influence of teacher professional development (mathematics knowledge training, mathematics education and mathematics training) on students' mathematics scores. The results of Model 5 analysis show that teachers' mathematics knowledge training $(b=-9.98, p=0.041)$ and mathematics education training $(b=-14.15, p=0.005)$ have significant influence on students' mathematics scores. The mathematics course training $(b=8.11, \mathrm{p}=0.078)$ had no significant effect on the student's mathematics scores. This shows that teachers' participation in mathematics knowledge training and mathematics education training will have a positive effect on classroom teaching, so that the average mathematics score of the students taught is higher. These three variables explain the student's average math score difference of $1.13 \%$.

\section{Conclusion and Discussion}

Teachers are a pivotal factor influencing students' learning outcomes. The study found that, in overall, the addition of teacher variables has led to a significant decline in teacher variability. The teacher characteristic variable explained $15.12 \%$ of the difference in the average mathematics score of the students; the teacher teaching variable explained $8.85 \%$ of the difference in the average mathematics score of the students; the teacher professional development variable explained $1.13 \%$ of the difference in the average mathematics score of the students. Specifically, the results of each variable's impact on student mathematics are also presented in Table 5. These findings provide a basis for improving teachers' classroom teaching, strengthening teachers' professional development, and formulating relevant educational policies.

\section{The Teacher's Teaching Age Has a Significant Impact on the Student's Mathematical Performance}

The results in Table 5 show that the teacher's teaching age can have a significant predictive effect on students' mathematics scores. At the same time, in the literature that has explored the relationship between teachers' teaching age and students' mathematics scores, the conclusions are not completely consistent. For example, the relationship between teachers' teaching age and the student's learning is positively related, or only affects the student's learning to a certain extent, or the two do not matter (Huang \& Xin, 2007; Zhang, 2012; Zhang, 2010; Xie, et al., 2008; Xin, et al., 2004). This shows that it is not the teacher's teaching age that has a direct impact on the students' mathematics scores. However, These factors affect teachers' understanding of the knowledge and grasp of the teaching process, making teachers with a longer teaching age pay more attention to the combination of mathematical knowledge and students' cognitive level and laws, thus showing that the students' mathematical results will be better. This shows that relevant education departments and schools should not exclude new teachers. They should pay more attention to the development trend of new teachers and provide more 
Table 5. The Influence of Teacher Factors on Students' Mathematics

Scores.

\begin{tabular}{|c|c|c|c|c|c|c|}
\hline \multirow{2}{*}{$\begin{array}{l}\text { Hierarchical } \\
\text { Linear } \\
\text { Model } \\
\end{array}$} & \multirow[b]{2}{*}{ Variable } & \multicolumn{2}{|l|}{ Fixed Effect } & \multicolumn{2}{|c|}{ Random Effect } & \multirow[b]{2}{*}{$\begin{array}{l}\text { Interpretation } \\
\text { Rate }\end{array}$} \\
\hline & & $\begin{array}{l}\text { Regression } \\
\text { Coefficient } \\
\text { (B) } \\
\end{array}$ & SEM & $\begin{array}{l}\text { Inter- } \\
\text { teachers }\end{array}$ & $\begin{array}{l}\text { Intra- } \\
\text { teachers }\end{array}$ & \\
\hline Zero Model & & & & $8,900.70$ & $4,107.92$ & \\
\hline \multirow{9}{*}{ Model 1} & & & & $7,196.61$ & $3,822.46$ & $19.15 \% / 6.94 \%$ \\
\hline & \multicolumn{3}{|c|}{ Student Background Variable } & & & \\
\hline & Gender & $4.04^{* * *}$ & 0.70 & & & \\
\hline & Age & $-6.92^{\star \star \star}$ & 0.61 & & & \\
\hline & $\begin{array}{l}\text { Family Book } \\
\text { Collection }\end{array}$ & $7.87^{\star \star \star}$ & 0.31 & & & \\
\hline & $\begin{array}{l}\text { Home Com- } \\
\text { puter }\end{array}$ & $7.31^{* * *}$ & 0.67 & & & \\
\hline & Home Desk & 0.19 & 0.75 & & & \\
\hline & $\begin{array}{l}\text { Mobile } \\
\text { Phone }\end{array}$ & 1.38 & 0.83 & & & \\
\hline & $\begin{array}{l}\text { Parental } \\
\text { Education }\end{array}$ & $8.66^{* * *}$ & 0.50 & & & \\
\hline \multirow{4}{*}{ Model 2} & & & & $8,474.77$ & $3,204.58$ & $/ 16.16 \%$ \\
\hline & \multicolumn{3}{|c|}{ Student Learning Motivation Variable } & & & \\
\hline & $\begin{array}{l}\text { Mathematical } \\
\text { Learning } \\
\text { Interest }\end{array}$ & $-7.31^{\star \star \star}$ & 0.39 & & & \\
\hline & $\begin{array}{l}\text { Mathematics } \\
\text { Self- } \\
\text { Confidence } \\
\end{array}$ & $-25.23^{* * *}$ & 0.52 & & & \\
\hline \multirow{7}{*}{ Model 3} & & & & $7,193.02$ & $3,204.52$ & $15.12 \% /$ \\
\hline & \multicolumn{3}{|c|}{ Teacher Characteristic Variable } & & & \\
\hline & $\begin{array}{l}\text { Teaching } \\
\text { Age }\end{array}$ & $1.09^{* * *}$ & $\begin{array}{l}0 . \\
18 \\
\end{array}$ & & & \\
\hline & Gender & $-8.98^{*}$ & 4.01 & & & \\
\hline & Education & $48.84^{* * *}$ & 3.36 & & & \\
\hline & $\begin{array}{l}\text { Mathematic } \\
\text { Major }\end{array}$ & $12.20^{* *}$ & 4.26 & & & \\
\hline & $\begin{array}{l}\text { Mathematics } \\
\text { Education }\end{array}$ & -5.25 & 3.82 & & & \\
\hline \multirow{6}{*}{ Model 4} & & & & $6,556.75$ & $3,204.09$ & $8.85 \% /$ \\
\hline & \multicolumn{3}{|c|}{ Teacher Teaching Variable } & & & \\
\hline & $\begin{array}{l}\text { Teaching } \\
\text { Expectation }\end{array}$ & $-23.53^{* * *}$ & 2.45 & & & \\
\hline & $\begin{array}{l}\text { Teaching } \\
\text { Cooperation }\end{array}$ & 3.94 & 2.29 & & & \\
\hline & $\begin{array}{l}\text { Teaching } \\
\text { Passion }\end{array}$ & $9.72^{* *}$ & 3.11 & & & \\
\hline & $\begin{array}{l}\text { Class Dis- } \\
\text { cussion }\end{array}$ & $18.01^{* \star *}$ & 2.33 & & & \\
\hline
\end{tabular}


(Continued)

\begin{tabular}{|c|c|c|c|c|c|c|}
\hline & Multimedia Use & $-11.90^{\star *}$ & 4.20 & & & \\
\hline & $\begin{array}{l}\text { Pay Attention To } \\
\text { Homework }\end{array}$ & -1.13 & 1.84 & & & \\
\hline & $\begin{array}{l}\text { Pay Attention To The } \\
\text { Exam }\end{array}$ & -5.21 & 3.90 & & & \\
\hline \multirow{5}{*}{ Model 5} & & & & $6,482.58$ & $3,204.15$ & $1.13 \% /$ \\
\hline & \multicolumn{6}{|c|}{ Teacher Professional Development Variable } \\
\hline & $\begin{array}{l}\text { Mathematical } \\
\text { Knowledge Training }\end{array}$ & $-9.98^{*}$ & 4.89 & & & \\
\hline & $\begin{array}{l}\text { Mathematics Educa- } \\
\text { tion Training }\end{array}$ & $-14.15^{\star \star}$ & 4.94 & & & \\
\hline & $\begin{array}{l}\text { Mathematics Course } \\
\text { Training }\end{array}$ & 8.11 & 4.61 & & & \\
\hline
\end{tabular}

Note: ${ }^{*}: P<0.05,{ }^{* *}: P<0.01,{ }^{* * *}: P<0.001$. Interpretation rate refers to the percentage of decrease in teacher-to-teacher variation between teachers and teachers compared to the previous model after adding a new factor.

channels for the communication between new teachers and expert teachers. This is more conducive to narrowing the differences in teaching mathematics among students.

\section{Teacher's Academic Qualifications, Mathematics Knowledge Training, and Mathematics Majors Will Significantly Affect Students'Mathematics Scores}

The results in Table 5 show that the higher the teacher's academic qualifications, the better the mathematics scores of the students in the taught class will be. Students who have participated in mathematics knowledge training have better math scores. Students in classes taught by non-mathematics teachers have higher math scores than those who were taught by teachers who graduated from mathematic major. Generally speaking, teachers with high academic qualifications have more knowledge of mathematics, and teachers who participate in mathematics knowledge training will have a better understanding of the methods of teaching mathematics. Comparing the influence of these three variables on students' mathematics scores, it is found that the mathematics knowledge and methods of teaching that teachers have had positive effects on students' mathematics scores. However, students in classes taught by non-mathematics teachers will have higher math scores. There may be two reasons for this. First, compared to non-mathematics teachers, those graduated from mathematic major have more knowledge, but their ability to teach mathematical knowledge to students in the corresponding grade is not as good as non-mathematics teachers. Second, the focus of the two types of teachers is different from that of the current basic education.

Teachers without background of mathematics major will pay more attention to the training of students' mathematics skills. Teachers of mathematics majors pay more 
attention to the cultivation of students' mathematical thinking and mathematics thinking. However, for the improvement of students' test scores, it is better to train students' math skills. In addition, mathematics education is designed to help students master the mathematics, skills, ideas, and methods necessary for modern life and further learning. Therefore, in the process of teaching, teachers can not choose the sea tactics solely for the test results, nor can they focus only on the improvement of mathematical thinking and neglect the students' ability to accept at this stage. This shows that the cultivation of mathematical knowledge and skills, mathematical ideas and methods complement each other. Teachers should pay attention to this and organically combine them, so that students can understand the ideas and methods of mathematics in the training of mathematics knowledge and skills. At the same time, it is recommended that the education department or school regularly organize mathematics knowledge training to provide more ways for teachers to master the methods of teaching mathematics.

\section{The Influence of Teachers' Mathematics Education Major and Mathematics Education Training on Students' Mathematical Achievement}

The results in Table 5 show that there is no significant difference in the mathematics scores of the students taught by the mathematics education majors and the nonmathematics education teachers. Students who have participated in mathematics education training have better math scores. Comparing the influence of two variables on students' mathematics scores, it is found that teachers master more mathematics education theories have positive effects on students' mathematics scores. However, the teaching effects of teachers in mathematics education and non-mathematics education teachers are not significantly different. The reason may be that the teaching of traditional mathematics education theory does not use actual cases as a carrier. Therefore, teachers cannot truly apply the learned education theory to classroom teaching, thus making the effect of educational theory learning greatly compromised. In view of this, it is recommended to combine educational theory and practice when teaching educational theory, to provide teachers with more practical teaching cases, or to answer the problems encountered by teachers in real teaching. In addition, the relevant education departments are also encouraged to regularly organize mathematics education training, and strive to implement education theory into classroom teaching.

Overall, the study has made some meaningful conclusions. At the same time, there are problems in this study, through the interpretation of inter-teacher variation. We find that the addition of teacher variables does cause a large decline in teacher-toteacher variation, but there are still large inter-teacher differences. There are two reasons for this: First, the TIMSS study is conducted once every four years, so the student's math scores are not continuous, and the characteristics of the student's current math scores cannot be linked to the teacher factors at this time. Secondly, the student's academic performance itself is affected by many factors, and is also affected by the initial mathematics scores, and the students' mathematics scores themselves may also dif- 
fer. Therefore, the influence of teacher variables on students' mathematics scores is still somewhat exploratory.

\section{References}

Bülent, A., \& Erden, M. (2006) The effects of primary school teachers' attitudes towards the mathematics achievement fourth grade students by gender. J Edu Faculty, 8(1): 1321.

Cao, Y.M., Yu, G.W. (2017) Research on the critical level of the critical pedagogical behaviors in middle school mathematics classroom. J Math Edu, 26(1): 2-6.

Dedrick, R.F. (2009) Multilevel modeling: A review of methodological issues and applications. Rev Edu Res, 79(1): 69-102.

Gao, X., \& Zhang, B. (2016) Research on the evaluation and compilation of question strings by high school mathematics teachers. J Math Edu, 25(3): 66-70.

Herlihy, C. (2005) State and local efforts to investigate the validity and reliability of scores from teacher evaluation systems. Teach Coll Rec, 116(1): 463-465.

Huang, H., \& Xin, T. (2007) The influence of teacher's classroom teaching behavior on students' academic achievements: A crosscultural study. Psychol Develop

Edu ,23(4):57-62.

Huang, X.F., Pang, Y.L., \& Li, S.Z. (2009) Inheritance and development of teaching behavior of mathematics classroom teachers: Comparative study of three video lessons. J Math Edu, 18(6): 54-57.

Huang, Y.C. (2016) Four elements of teacher's classroom teaching behavior. J Math Edu, 25(1): 72-74.

Li, Q., Ni, Y.J. (2006) Multi-level analysis of the influence of teacher variables on pupils' math learning achievements. J Teach Edu, 18(3): 74-80.
Peterson, P.L., Marx, R.W., \& Clark, C.M. (1978) Teacher planning, teacher behavior, and student achievement. Am Edu Res J, 15(3): 417-432.

Walsh-Cavazos, S.A. (1994) Study of the effects of a mathematics staff development module on teachers' and students' achievement. Texas Tech Univ, Texas.

Xie, M., Xin, T., \& Li, D.W. (2008) The influence of teacher qualification and career development factors on students' mathematical achievements: A cross-cultural comparison. Stud Psychol Behav, 6(2): 124-129.

Xin, T., Xu, Z., \& Tatsuoka, K. (2004) Linkage between teacher quality, student achievement and cognitive skills: A rule-space model. Stud Edu Eva, 30(3): 205-223.

Zhang, W.J. (2010) The influence of teacher variables on mathematical achievements in the fourth grade of primary school: A valueadded study. Chin J Edu, 06(2): 69-76.

Zhang, Y.M. (2012) An empirical study of the influence of teacher factors and student factors on students' academic achievement: A Hierarchical linear model analysis based on large-scale test data. J Teach Edu, 24(4):56 62.

Zhao, J.et al. (2013) The impact of professional development practice of Chinese teachers on student achievement: an analysis based on surveys in five cities. Global Edu Outlook, 42(2): 22-33.

Zhou, C., \& Bao, J.S. (2012) The strategy of forming students' high level mathematical thinking: The viewpoint of frontline teachers. J Math Edu, (4): 37-39. 
Bai, et al. Teacher Variables and Students' Mathematical Achievements.

Received: 02 August 2019

Revised: 22 September 2019

Accepted: 19 October 2019

The Chinese version of this article has been published in Teacher Edu Res 2019; 31(3):70-76. The English version has been authorized for being publication in BECE by the author(s) and the Chinese journal.

白胜南, 韩继伟, 李灿辉. 教师变量对学生数学成绩影响的研究. 教师教育研究, 2019, 31(3):70-76. 